УДК 537.622

\title{
Micromagnetic Simulation of Magnetization Reversal Processes in Thin Obliquely Deposited Films
}

\author{
Platon N. Solovev* \\ Andrey V. Izotov ${ }^{\dagger}$ \\ Boris A. Belyaev $\ddagger$ \\ Kirensky Institute of Physics SB RAS \\ Akademgorodok, 50/38, Krasnoyarsk, 660036 \\ Institute of Engineering Physics and Radio Electronics \\ Siberian Federal University \\ Svobodny, 79, Krasnoyarsk, 660041
}

Russia

Received 20.08.2016, received in revised form 10.10.2016, accepted 07.11.2016

\begin{abstract}
The magnetization reversal processes in thin obliquely deposited films were studied by means of micromagnetic modeling. Thin film structures for micromagnetic study were generated by Monte Carlo film growth simulator. Using obtained hysteresis loops for the generated films, we retrieved coercivity and remanent magnetization as a function of the deposition angle $\alpha$. The results showed that for films with $\alpha<65^{\circ}$ the magnetization reversal occurred via coherent rotation of magnetic moments, whereas samples generated with larger deposition angles reverse their magnetization by the formation of complex quasidomain magnetic structures. The numerical results are in a good accordance with the previously reported experimental measurements.
\end{abstract}

Keywords: film growth simulation, hysteresis loops, micromagnetic simulation, oblique deposition. DOI: 10.17516/1997-1397-2016-9-4-524-527.

\section{Introduction}

Oblique deposition is a well-known method that allows for fabrication of thin films with complex non-uniform columnar morphology that is governed by the competition between geometrical shadowing and limited diffusion processes [1]. In the case of magnetic materials, this columnar microstructure leads to the modification of magnetic properties of the resulting films. By controlling the deposition angle (the angle between a particles flux and a film normal) during films growth, it is possible to produce samples with desirable values of a magnetic uniaxial anisotropy [2] and coercivity [3]. These oblique magnetic films have great potential for use in a wide range of applications, including data storage [4] and microwave devices [5]. Therefore, it is important to understand better the relation between microstructural and static magnetic properties of such samples. However, while there are numerous experimental investigations of obliquely deposited thin magnetic films (see, for example, Ref. [2]), to our knowledge, only a few theoretical works are present $[6,7]$. In this work, we use Monte Carlo film growth simulator

\footnotetext{
*platon.solovev@gmail.com

†iztv@mail.ru

‡belyaev@iph.krasn.ru

(c) Siberian Federal University. All rights reserved
} 
to generate three-dimensional thin-film structures with columnar morphology for simulation of their magnetic properties by means of micromagnetic modeling. The focus of this paper lies on the influence of the deposition angle on the magnetization reversal processes in oblique simulated films.

\section{Methods}

Investigated thin-film structures were generated by our developed Monte Carlo thin film growth simulator [8]. We modeled the oblique deposition of thin-film structures of size $256(x) \times 256(y) \times 80(z) \Delta$ (where $\Delta$ is a size of a single cubic deposited particle) for a set of deposition angles in the range $0^{\circ}-85^{\circ}$. Simulated films were represented as three-dimensional arrays of zeroes (voids) and ones (particles). In order to improve the reliability of the obtained results, for each deposition angle $\alpha$ ten independent simulations of a film growth were performed. Obtained samples exhibited tilted columnar microstructure reproducing that of experimental obliquely deposited films [8]. In order to study numerically magnetic properties of these simulated oblique films we employed our micromagnetic simulation software $[9,10]$. In micromagnetic analysis, each cell of the three-dimensional array occupied by a particle was characterized by an averaged value of a magnetic moment $M$ with the magnetization saturation $M_{s}$ (for unoccupied cells $\left.M_{s}=0\right)$. We used magnetic parameters typical for permalloy $\left(\mathrm{Ni}_{80} \mathrm{Fe}_{20}\right): M_{s}=860 \mathrm{G}$, exchange constant $A=1.3 \times 10^{-6} \mathrm{erg} / \mathrm{cm}$. We also set magnetic anisotropy field $H_{k}=0$, thus magnetic anisotropy only of magnetostatic origin was presented in the investigated films. We estimated the size of a cubic particle as $\Delta=0.5 \mathrm{~nm}$. Note that for both film growth simulation and micromagnetic modeling in-plane periodic boundary conditions were used.

\section{Results and discussion}

Using our micromagnetic modeling software, we calculated hysteresis loops for each simulated film, with external magnetic field $H$ directed parallel and orthogonal to the deposition plane. Note that the deposition plane is usually defined as a plane that is parallel to the deposited particles flux and orthogonal to the film surface [2]. As an example, Fig. 1a shows averaged over the set of ten films loops obtained for the deposition angles $\alpha=0^{\circ}, 45^{\circ}, 75^{\circ}$, and $85^{\circ}$. From these loops, we derived the coercivity $H_{c}$ and the remanent magnetization $M_{r}$, which are plotted in Fig. $1 \mathrm{~b}$ as a function of the deposition angle. The results of the micromagnetic modeling demonstrate that the coercivity of the normally deposited film is about 5 Oe and its magnetic parameters are almost independent on the external field orientation. However, for films deposited at oblique angles starting from $\alpha \approx 20^{\circ}$, the hysteresis loops have a shape that is characteristic for films with a well-defined uniaxial magnetic anisotropy, with the easy axis lies orthogonally to the deposition plane. Loops calculated for the external field oriented along easy axis have a good squareness, while curves obtained with the field lies along hard axis demonstrate almost complete absence of the hysteresis. The analysis of the magnetic microstructure in these simulated films shows that the magnetization reversal occurs by coherent rotation of the magnetic moments. However, the hysteresis loops change their shape for films produced at larger incidence angles $\left(>65^{\circ}\right)$, as one can see in Fig. 1a. This is related to the enhancement of the non-uniformity in the microstructure of the films with increase of the deposition angle [8] that leads to the formation of complex quasi-domain magnetic configurations. For deposition angle $\alpha=75^{\circ}$ the coercive forces for both directions of the field $H$ are almost equal. Finally, with further increasing of 
the deposition angle, the reorientation of the easy axis direction is observed. In this case, the magnetization easy axis is parallel to the deposition plane.
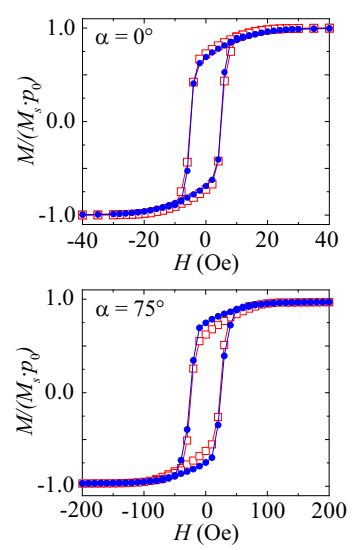

(a)
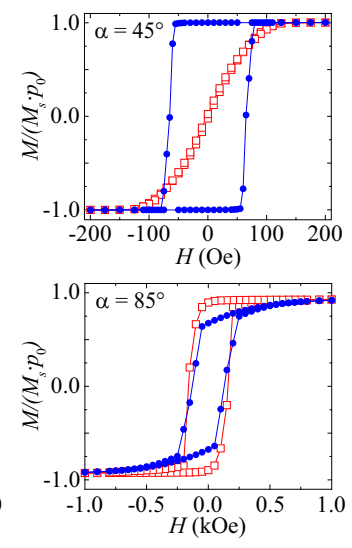

(b)

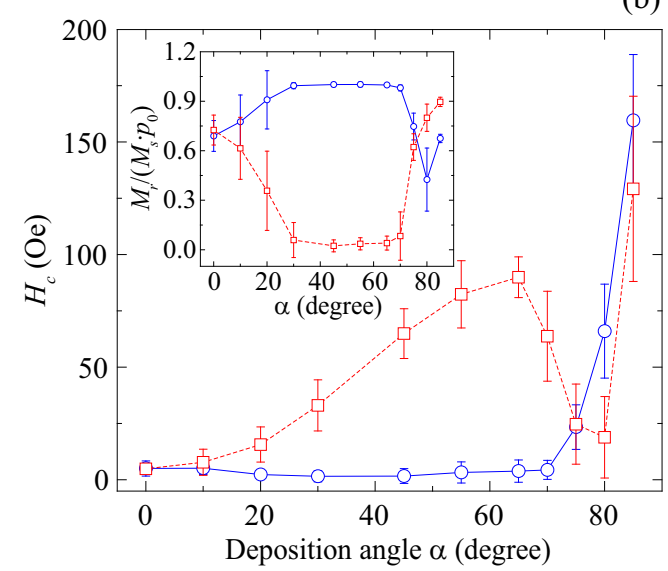

Fig. 1. (a) Hysteresis loops calculated for films simulated at different deposition angles $\alpha$ ( $p_{0}$ is the packing density of the films). (b) Coercive force $H_{c}$ as a function of the deposition angle. Inset shows dependence of the remanent magnetization on the deposition angle. The error bars indicate the range of values. In all figures, square (circle) symbols show results for the case when the external field $H$ was oriented parallel (perpendicular) to the deposition plane

We also found that for glancing deposition angles $\left(>75^{\circ}\right)$, the magnetization configuration resembling stripe domain pattern was formed in the investigated samples. The films generated with such large deposition angles consist of conglomerates of weakly connected tilted columns. Therefore, it is preferable for magnetic moments in the nearby columns to have an opposite directions. In this case, the magnetic flux will close and the magnetostatic energy associated with magnetic poles on the opposite surfaces of the film will be minimized. As a result, for the films deposited at glancing angles much larger magnetic fields are needed for their saturation compared to the films obtained with the smaller $\alpha$. The formation of such magnetic structure in the films leads to the characteristic tilt of the hysteresis loops (see Fig. 1a, $\alpha=85^{\circ}$ ). For the same reason, for the samples with $\alpha>75^{\circ}$ the calculated values of $H_{c}$ and $M_{r}$ are close for the orthogonal directions of the external magnetic field. We note that these numerical results are in a good accordance with the previously reported experimental measurements $[2,3]$.

\section{Conclusion}

In summary, by combining the film growth simulations and micromagnetic modeling we studied the magnetization reversal processes in thin obliquely deposited films. It was found that because of the formation of the anisotropic columns aggregations the simulated films exhibited a uniaxial magnetic anisotropy induced by the magnetic dipolar mechanism. For deposition angles $\alpha<65^{\circ}$ the magnetization reversal occurred by the rotational mechanism, while for films obtained with the larger angles the reversal occurred through the formation of the quasidomain magnetic configurations. The obtained results demonstrate that the proposed simulation approach is a useful tool which can be used not only to reproduce but also to predict magnetic properties of magnetic objects with a complex microstructure.

This work was supported by Russian Science Foundation (project no. 16-12-10140). 


\title{
References
}

[1] A.Barranco, A.Borras, A.R.Gonzalez-Elipe, A.Palmero, Perspectives on oblique angle deposition of thin films: From fundamentals to devices, Progr. Mat. Science, 76(2016), 56.

[2] H.Kranenburg, C.Lodder, Tailoring growth and local composition by oblique-incidence deposition: a review and new experimental data, Mat. Science and Eng., R11(1994), 295.

[3] C.Quiros, L.Peverini, J.Diaz, A.Alija, C.Blanco, M.Velez et al., Asymmetric grazing incidence small angle x-ray scattering and anisotropic domain wall motion in obliquely grown nanocrystalline Co films, Nanotechnology, 25(2014), 335704.

[4] P.-O.Jubert, A.Vanhaverbeke, A.Bischof, R.Allenspach, Recording at large write currents on obliquely evaporated medium and application to a multilevel recording scheme, IEEE Trans. Magn., 46(2010), 4059.

[5] J.Vergara, C.Favieres, Increased ultra high frequency magnetic susceptibility in nanopatterned nanolayers with strong exchange coupling, J. Phys. D: Appl. Phys., 48(2015), 435003.

[6] E.Munster, Calculation of the magnetic properties of oblique-incidence thin films, J. Magn. Magn. Mater., 92(1990), 279.

[7] J.L.Bubendorff, S.Zabrock, G.G.S.Hajjar, R.Jaafar, et al., Origin of the magnetic anisotropy in ferromagnetic layers deposited at oblique incidence, Europhys. Lett., 75(1)(2006), 119.

[8] B.A.Belyaev, A.V.Izotov, P.N.Solovev, Growth simulation and structure analysis of obliquely deposited thin films, Russ. Phys. J., 59(2016), 301.

[9] B.A.Belyaev, A.V.Izotov, A.A.Leksikov, Micromagnetic calculation of the equilibrium distribution of magnetic moments in thin films, Phys. Sol. State, 52(2010), 1664.

[10] A.V.Izotov, B.A.Belyaev, A method for computing the microwave absorption spectrum in a discrete model of a ferromagnetic, Russ. Phys. J., 53(2011), 900.

\section{Микромагнитное моделирование процессов перемагничивания в тонких наклонноосажденных \\ пленках}

\section{Платон Н. Соловьев \\ Андрей В. Изотов \\ Борис А. Беляев}

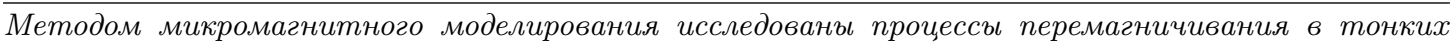
наклонно-осажденных пленках. Тонкопленочные структуры для микромагнитного анализа бъли получены с помощъю программы моделирования роста пленок, основанной на методе МонтеКарло. Из петель гистерезиса, полученных для сгенерированных пленок, были определены зависимости коэриитивной силь и остаточной намагниченности от угла осаждения $\alpha$. Результаты исследований показали, что для пленок с $\alpha<65^{\circ}$ перемагничивание осуществляется посредством когерентного вращения магнитных моментов, тогда как для образцов полученных при больших углах осаждения перемагничивание осуществляется через формирование сложсных квазидоменных магнитных структур. Результаты моделирования хорошо согласуются с ранее опубликованными данными эксперименталъных измерений.
\end{abstract}

Ключевые слова: моделирование роста пленок, петли гистерезиса, микромагнитное моделирование, наклонное осаждение. 